\title{
THREE NEW SPECIES AND TWO NEW RECORDS OF THE GENUS GLOSSODORIS FROM JAPAN
}

\author{
$\operatorname{AUTHOR(S):~}$ \\ Baba, Kikutaro
}

\section{CITATION:}

Baba, Kikutaro. THREE NEW SPECIES AND TWO NEW RECORDS OF THE GENUS GLOSSODORIS FROM JAPAN. PUBLICATIONS OF THE SETO MARINE BIOLOGICAL LABORATORY 1953, 3(2): 205-211

\section{ISSUE DATE:}

1953-12-20

URL:

http://hdl.handle.net/2433/174468

RIGHT: 


\title{
THREE NEW SPECIES AND TWO NEW RECORDS OF THE GENUS GLOSSODORIS FROM JAPAN ${ }^{1)}$
}

\author{
KiKUTARô BABA
}

Biological Laboratory, Osaka University of Liberal Arts

\section{With 6 Text-figures}

The following is a revised list of the Japanese species belonging to Glossodoris and the allied genus Noumea (see also BABA, 1949).

1. Glossodoris lineolata (vaN HASselt, 1824). Kurosuji-umiushi

2. Glossodoris marginata (PEASE, 1860). Shirahime-umiushi (new name)

3. Glossodoris decora (PeAse, 1860) $=$ G. setoensis (BABA, 1938). (See Allan 1947). Seto-iroumiushi

4. Glossodoris festiva (ADAMs, 1861) $=$ G. marenzelleri (BERGH, 1881). Aoumiushi

5. Glossodoris pallescens (BERGH, 1875). Shiro-umiushi

6. Glossodoris thalassopora (BERGH, 1879).

7. Glossodoris alderi (COLlingwood, 1881) =G. reticulata (PEASE, 1866). Sarasaumiushi

8. Glossodoris aureopurpurea (ColliNGwood, 1881). Komon-umiushi

9. Glossodoris sibogae (BERGH, 1905). Siboga-umiushi

10. Glossodoris clitonota (BERGH, 1905). Sesuji-umiushi

11. Glossodoris katoi BABA, 1938. Katô-iroumiushi (new name)

12. Glossodoris maritima BABA, 1949. Ryûmon-iroumiushi

13. Glossodoris placida BABA, 1949. Usuiro-umiushi

14. Glossodoris sagamiensis BABA, 1949. Sagami-iroumiushi

15. Glossodoris florens BABA, 1949. Hanairo-umiushi

16. Noumea nivalis BABA, 1937. Shirayuki-umiushi

17. Noumea parva BABA, 1949. Hime-iroumiushi

18. Noumea purpurea BABA, 1949. Fujiiro-umiushi

The following species are here added to the above list.

1) Contributions from the Seto Marine Biological Laboratory, No. 218.

Publ. Seto Mar. Biol. Lab., III (2), 1953. (Article 19) 


\section{Glossodoris shirarae BABA, n. sp.}

\section{Shirara-iroumiushi (new name)}

(Fig. 1 ; Fig. 6, A-B)

The animals of this new species differ from those of Glossodoris pallescens (BERGH) and other allied forms in some points of the body colouring. They are about 10-25 $\mathrm{mm}$ in total length. The back is very finely tuberculated. General ground-colour whitish above and below, the rhinophores and the gills colourless, the back scattered with a varying number of purple (not black nor carmine red) spots which may also be found on the underside of the mantle. The intramarginal yellow band of the mantle continuous or in places interrupted by white. It is especially marked by having a series of indentations on inside. Labial disk and radula as usual in the genus. The elements of the former bifid at tip. Radula formula $45 \times 37.0 .37$. First lateral denticulated on both sides, the next laterals with 4-10 denticles on outer margin.

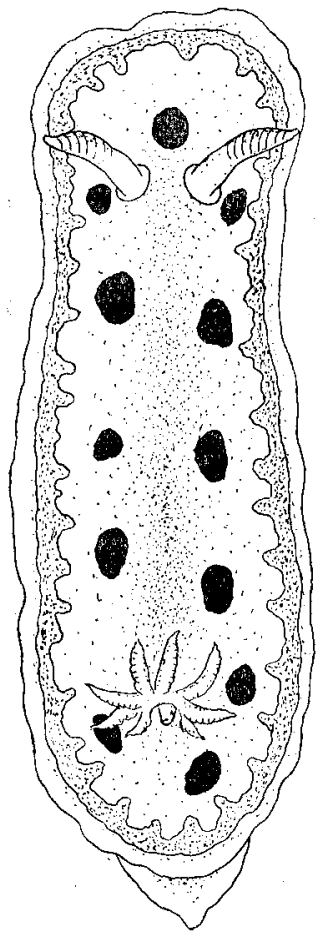

Fig. 1.

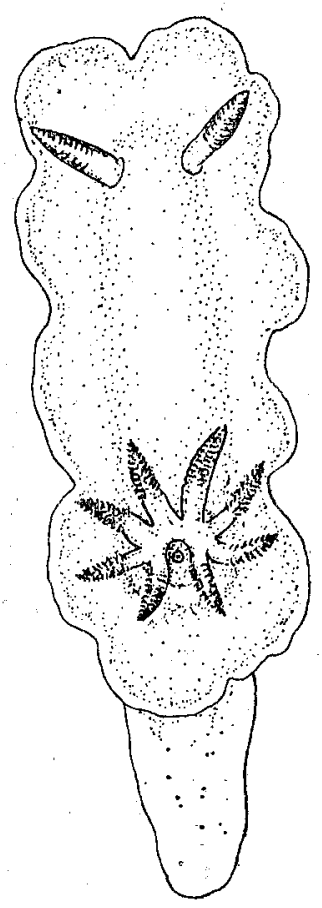

Fig. 2.

Fig. 1. Glossodoris shirarae (Seto, Mar. 30, 1953. Total length $12 \mathrm{~mm}$ ).

Fig. 2. Glossodoris nona (Sagami Bay, Mar. 20, 1951. Total length 25mm). 
Loc.: Seto, Kii (Aug. 1951, June 1952 and Mar. 1953, 6 sps., coll. by Messrs. HAMATANi and YAMAMoto and the present writer); Fushiki and Amaharashi, Toyama Bay (Aug. 1951, 2 sps., coll. by Mr. ABE); Misaki, Sagami Bay (July 1953, 1 sp., coll. by His Majesty's Biological Laboratory).

As there appears to be no species with which the present nudibranch can be identified with certainty, I have given it the specific name shirarae, after the local name of Seto, Kii.

2. Glossodoris multituberculata BABA n. sp.

Renge-umiushi (new name)

(Fig. 3; Fig. 6, C-E)

A strongly tuberculated glossodorid. Length about $20 \mathrm{~mm}$. Back ornamented with large, elevated, bluntly conical tubercles, with smaller ones between them and
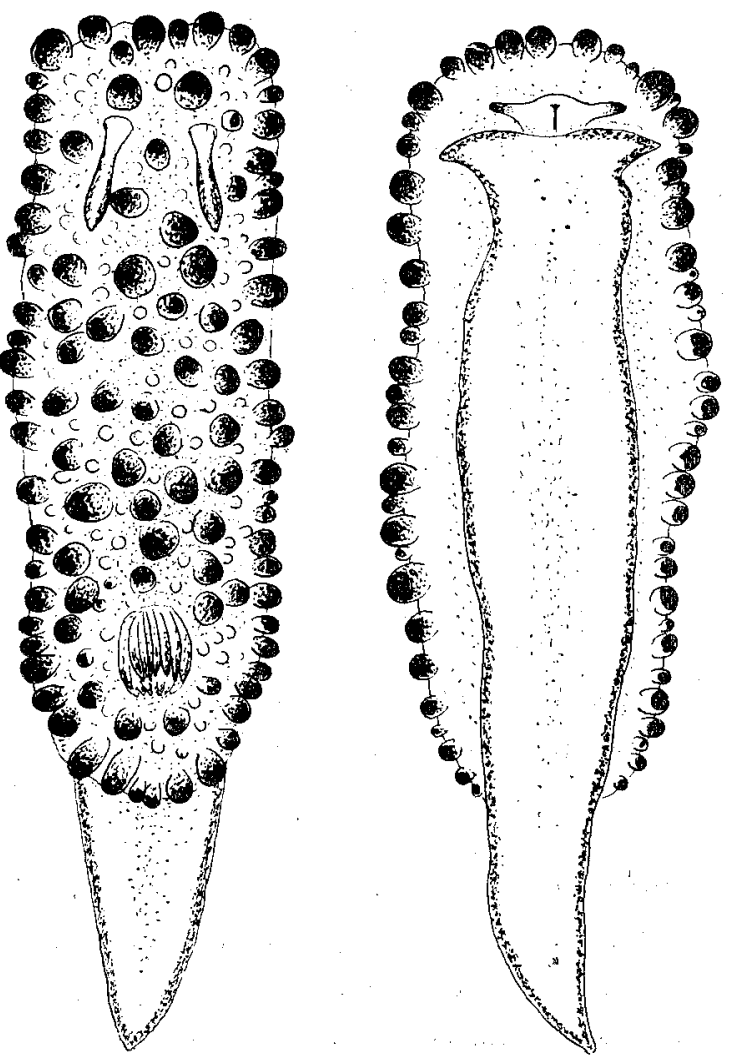

Fig. 3. Glossodoris multituberculata (Seto, Aug. 11, 1951.

Total length $20 \mathrm{~mm}$ ). Dorsal and ventral views. 
around the branchial opening. With 4 marginal cysts on postero-ventral edge of mantle. General ground-colour almost everywhere chrome-yellow, becoming slightly paler towards the margin of the mantle. Dorsal tubercles tipped with purple. Rhinophores, gills, foot-margin and tip of the oral tentacles purple. Elements of the labial disk bifid at tip. Radula formula $65 \times 30.0$. 30. Rachidial plate not marked. First lateral with 4-5 denticles on either side of the median cusp. Succeeding laterals denticulated on outer edge, the number of denticles increasing from 4 up to 10 .

Loc.: Seto, Kii (Aug. 1951, 1 sp., coll. by Mr. Hamatani).

The present species differs from Glossodoris nodulosa (RERGH) in the type of the radula teeth, and from G. papulosa (BERGH) in the size and arrangement of the dorsal tubercles.

\section{Glossodoris nona $\mathrm{BABA}$, n. sp.}

Shiraume-umiushi (new name)

(Fig. 2; Fig. 6, F-G)

The simple but fairly unique coloration of this species consists of pure white body-colour with yellow rhinophores and yellow gills, and a number of opaque white spots sparsely set around the mantle-margin. Length of body $25 \mathrm{~mm}$. Labial disk a belt of bifid rads. Radula formula $65 \times 40.0 .40$. First lateral not differentiated ( $c f$. Noumea nivalis $\mathrm{BABA}$ ), and with 4-5 denticles on both sides. Succeeding laterals denticulated on outer margin only, the number of denticles varying from 4 to 10 .

Loc.: Amadaiba, Sagami Bay, $80 \mathrm{~m}$ (Mar. 1951, 1 sp., coll. by His Majesty's Biological Laboratory).

This species is here regarded as new, with the name nona which implies "Miss" in Malay language.

4. Glossodoris fidelis (KELAART, 1858)

$=$ G. flammulata (BERGH, 1905)

Fujinami-umiushi (new name)

(Fig. 4 ; Fig. 6, H-I)

A beautifully coloured glossodorid about $15 \mathrm{~mm}$ in length. The median part of the back is yellow. It is surrounded by an intramarginal band of purple-red, which turns to orange-yellow near the outer edge of the mantle. On inside the band is irregular, thus sending off a number of tooth-like prolongations directed inwardly. A fine thread of opaque white is visible edging the inner border of the purple-red band. Rhinophores black. Gills 7, also black-tinted. Underside of body yellowish 
white. Elements of the labial disk bifid at tip. Radula formula $60 \times 45.0 .45$. First lateral denticulated on both sides, the next laterals with 7-8 denticles on outer margin.

Loc.: Seto, Kii (July 1953, 1 sp., coll. by Mr. Yамamoto).

Dist.: Indo-Pacific (Ceylon, 'Insel Pajunga,' New Caledonia).
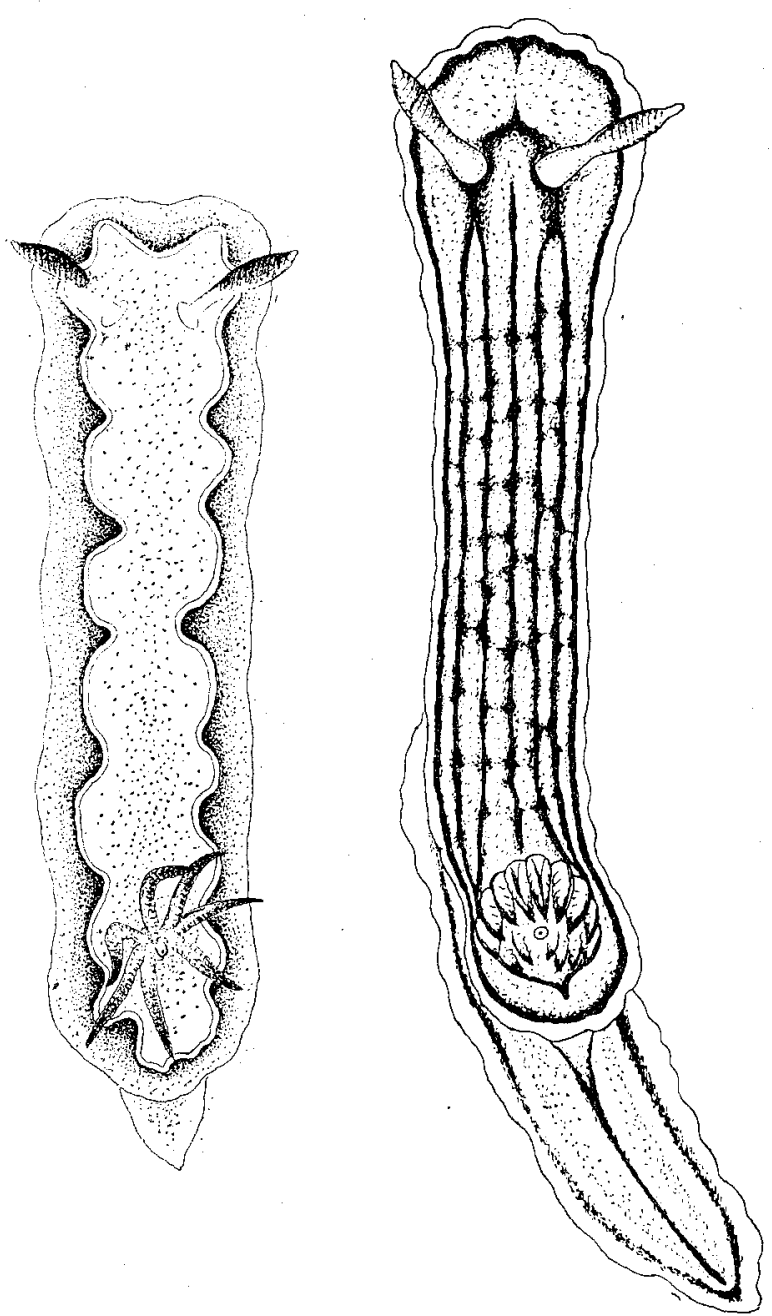

Fig. 4.

Fig. 5.

Fig. 4. Glossodoris fidelis (Seto, July 28, 1953. Total length $15 \mathrm{~mm}$ ). After the original figure taken by Mr. YAMAMOTO.

Fig. 5. Glossodoris hilaris (Seto, June 22, 1951. Total length $12 \mathrm{~mm}$ ). 


\section{Glossodoris hilaris (BERGH, 1890)}

\section{Kuchinashi-iroumiushi (new name)}

(Fig. 5 ; Fig. 6, J-K)

The animals before me appear to be a colour variety of hilaris, and correspond in all respects to Chromodoris lineata of ELIOT (1904, pp. 396-397, pl. 24, fig. 7) from Zanzibar. Total length of body from $15-25 \mathrm{~mm}$. Back ornamented with 5 longitudinal lines of bright purple, of which the median one is obliterated in the type of hilaris
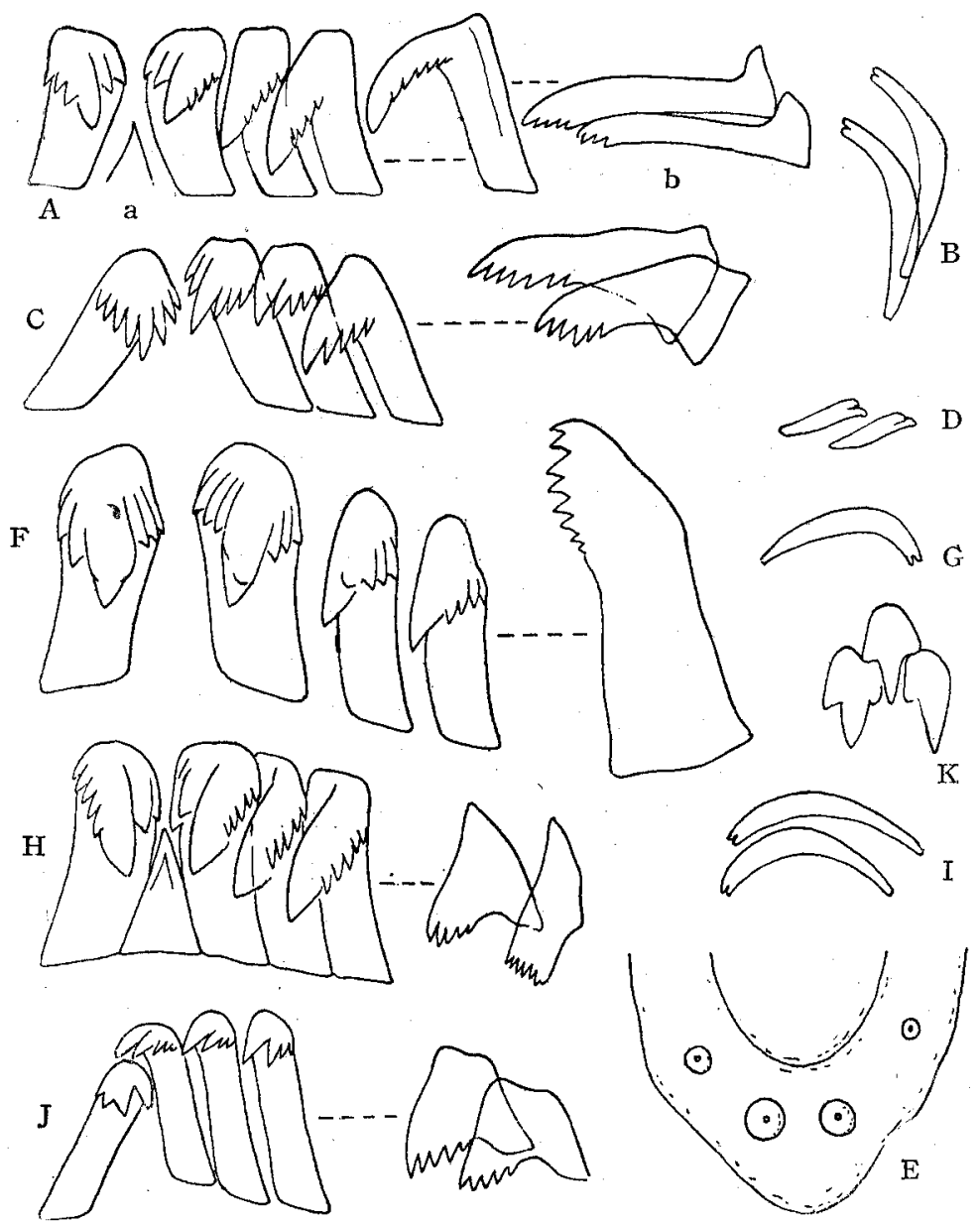

Fig. 6. A-B. Glossodoris shirarae; C-E. Glossodoris multituberculata; F-G. Glossodoris nona; H-I. Glossodoris fidelis; J-K. Glossodoris hilaris. A. A half-row of radula $(\times 550)$, a. innermost laterals, b. outermost laterals. C. Ditto $(\times 550)$. F. Ditto $(\times 270)$. H. Ditto $(\times 550)$. J. Ditto $(\times 550)$. B, D, G, I, K. Elements of the labial disk. E. Postero-ventral margin of mantle, showing the opening of the cysts. 
(BERGH 1890, pp. 935-937, pl. 86, fig. 4; pl. 87, figs. 11-15), and the rest are apt to fuse together in front and behind so as to enclose the rhinophores and the gills. Sides of body with 2 purple lines. A purple line also surrounding the mantle, the foot-brim and the gill-opening. General ground-colour of back and sides chrome-yellow, the sole whitish, the rhinophores and the gills vermilion. Elements of the labial disk mace-shaped with two lateral protuberances. Radula formula $50 \times 28-30.0 .28-30$. All the lateral teeth bicuspidate, each having a few accessory denticles on outside.

Loc.: Seto, Kii (July 1939, June \& Sept. 1951, 3 sps., coll. by Mr. Yамamoto).

Dist.: Indian Ocean (Zanzibar).

In concluding I wish to tender my hearty thanks to Messrs. Iwao HAMATANI, Torao YAMAMOTO and Takeo ABE for their willing assistance in collecting and studying these beautiful nudibranchs at Seto, Kii or at Abugashima, Toyama Bay. A part of the material was kindly delivered to me by the courtesy of His Majesty's Biological Laboratory.

\section{LITERATURE}

AllaN, J. 1947. Nudibranchia from the Clarence River Heads, North Coast, New South Wales. Rec. Austr. Mus., vol. 21, no. 8.

BABA, K. 1949. Opisthobranchia of Sagami Bay, collected by His Majesty the Emperor of Japan. Iwanami Shoten, Tokyo.

BERGH, R. 1890. Die Nudibranchien des Sunda-Meeres. Mal. Unters., Hft. 17. 1905. Die Opisthobranchiata der Siboga-Expedition. Siboga-Exped., Monogr. 50

ELIOT, C. 1904. On some nudibranchs from East Africa and Zanzibar. 4. Proc. Zool. Soc. London, 1904, vol. 1.

PRUVOT-FOL, A. 1951. Révision du genre Glossodoris Ehrenberg. Journ. de Conchyliol., vol. 91 , no. 3 . 